\title{
COMBATE AO NIILISMO E AO TOTALITARISMO EM CAMUS
}

\author{
UM CONTRAPONTO TEATRAL E FILOSÓFICO ÀS CONCEPÇÕES LÚDICAS E ESTÉTICAS DA EXISTÊNCIA
}

Emanuel R. Germano ${ }^{1}$

RESUMO: A partir de uma leitura da peça Calígula, elaborada entre 1941 e 1943, procurar-se-á contribuir na restituição das preocupações éticas, políticas e filosóficas em cena no teatro de Albert Camus, analisando o sentido de sua expressão teatral no contexto de dois combates, ao niilismo filosófico e ao totalitarismo político de seu tempo. Observaremos em Calígula um importante registro do amadurecimento das leituras de duas heranças filosóficas relevantes na formação intelectual de Camus, Nietzsche e Heráclito, à luz da experiência do totalitarismo, observando e ressaltando com isso a amplitude de seu intertexto filosófico e a importância do aporte ético e político de Camus como pensador multifacetado, engajado nos enfrentamentos históricos e solicitações críticas de seu tempo.

PALAVRAS-CHAVE: totalitarismo, filosofia, niilismo, nietzschiano, heraclitiano, poder.
ABSTRACT: Based on a reading of the play Caligula, produced between 1941 and 1943, the goal of the present study is to contribute to the restitution of ethical, political and philosophical concerns that took place in the theatre of Albert Camus, analyzing the meaning of his theatrical expression in the context of two battles, against the philosophical nihilism and against the political totalitarianism of his time. We observed in Caligula an important record of maturation in the interpretations of two relevant philosophical legacies in Camus' intellectual formation, Nietzsche and Heraclitus, in the light of the experience of totalitarianism, observing and highlighting both the amplitude of his philosophical intertext and the importance of the ethical and political contribution of Camus as a multifaceted thinker, engaged in historical confrontations and critical requests of his time. KEYWORDS: totalitarianism, philosophy, nihilism, Nietzschean, Heraclitean, power

Escrita entre 1941 e 1943, a peça teatral Calígula de Albert Camus integra, ao lado de O Estrangeiro e de 0 Mito de Sísifo a intitulada "trilogia do absurdo", como chama o filósofo argelino, em seus cadernos íntimos, a tríade de trabalhos que sintetiza suas preocupações éticas e seus diagnósticos de civilização de juventude: "Terminado Sísifo. Os três Absurdos estão terminados"2 (CAmus, 2006, p. 920, tradução nossa).

Como nos outros trabalhos de juventude de Camus, em Calígula, a expressão narrativa está vinculada à escolha de um estilo filosófico norteado pela intuição, pela sensibilidade, pela recusa do reducionismo sistêmico, em contraste com o dogmatismo formalista de muitas filosofias totalizantes de seu tempo:

a escolha de escrever por imagens mais do que por raciocínios é revelador de um certo pensamento que lhe é comum, persuadido da inutilidade de todo princípio de explicação e convencido da mensagem instrutiva da aparência sensível [...]. É uma culminação de uma filosofia muitas vezes não manifesta, sua ilustração e seu coroamento. Mas ela só se completa pelos subentendidos desta filosofia. (CAmus, 2004, p. 116)

1 Emanuel R.Germano é Professor Doutor Adjunto II de Ética e Filosofia Política no Curso de Filosofia do Instituto de Cultura e Arte da Universidade Federal do Ceará. Contato: emanuel.germano@ufc.br

2 Entretanto, cremos poder considerar a peça O Equívoco, esboçada na primavera de 1939,escrita definitivamente durante a ocupacão em 1943e encenada em 1944. um "auarto polo" do absurdo na criacão de Camus. 
"Só se pensa por imagens. Se você quer ser filósofo, escreva romances" (CAmus, 2006, p. 800, tradução nossa). Desde os cadernos íntimos de janeiro de 1936, Camus já exprimia a necessidade de recorrer à imagem para captar os dramas concretos da existência, com a acuidade exigida por seu paradigma realista de filosofia, ancorado na tradição dos moralistes franceses do século XVII e dos literatos filósofos dos séculos XVIII e XIX, "Sade, Melville, Stendhal, Dostoievsky, Proust, Malraux, Kafka, para só citar alguns" (CAmus, 2004, p. 116). Contra o caráter abstrato das doutrinas, Camus contrasta a dimensão ética e interrogante da imagem:

todos os problemas recuperam sua lâmina. A evidência abstrata se retira diante do lirismo das formas e das cores. Os conflitos espirituais se encarnam e voltam a encontrar seu abrigo miserável e magnífico no coração do homem.(CAmus, 2004, p.64).

Em Camus "cada palavra engaja", cada imagem é testemunho e possui uma dimensão ética. Como diz Camus em O Mito de Sísifo, "o que estas imagens propõem não são morais, nem tampouco implicam juízos: são ilustrações". (CAmus, 2004, p. 105).

Por exemplo, numa conferência nos Estados Unidos intitulada A Crise do Homem, nota-se a importância ética da imagem, na verdade uma coletânea de imagens de guerra, não como veículo de imposição de uma moral objetiva, mas à maneira do "contradiscurso" moraliste, conferindo rosto aos dramas humanos. Imagens de guerra utilizadas como denúncia e como testemunho, esforço de delineamento descritivo dos impasses éticos de uma história vivida e ainda viva:

1. Em um prédio da Gestapo de uma capital Europeia, depois de uma noite de interrogatório, dois acusados ainda sangrando se encontram algemados e a zeladora do prédio I [faz cuidadosamente a limpeza], o coração em paz visto que ela sem dúvida tomou seu café da manhã. À recriminação de um dos torturados, ela responde com indignação, com uma frase que, traduzida em francês, seria algo como: "não me ocupo do que fazem os meus locatários."

2. Em Lyon, um dos meus camaradas foi retirado de sua cela para um terceiro interrogatório. Como Ihe haviam cortado as orelhas, por ocasião de um interrogatório precedente, ele usava uma bandagem em volta da cabeça. O oficial alemão que o conduziu é o mesmo que já assistiu às primeiras sessões e, não obstante, é ele que lhe pergunta com uma nuance de afeição e de solicitude na voz: "Então, como vão as orelhas?"

3. Na Grécia [...] um oficial Alemão se prepara para fuzilar três irmãos que tomara como reféns. A velha mãe se joga a seus pés e ele consente poupar-lhe apenas um dos filhos, mas com a condição de que ela própria designe qual. Como ela não consegue decidir-se, o oficial se posiciona para atirar. Ela escolhe o mais velho, visto que ele se encarregava da família, mas de um só golpe, ela condenou os outros dois como queria o oficial alemão.

4. Um grupo de mulheres deportadas, no meio das quais se encontra uma camarada nossa, é repatriada à França pela Suíça. Logo na entrada do território suíço, elas percebem um enterro civil. E este espetáculo único as faz cair numa gargalhada histérica: "É assim que tratam os mortos aqui", elas dizem. (CAmus, 2006, p. 738-739, tradução nossa)

3 Notemos que no estágio atual do "terrorismo de estado", é toda a política internacional que se rege por esta dubiedade moral, incluindo aí os organismos humanitários, instalados numa atitude paliativa que Sartre intitulava em Situações IV de "a moral da cruz-vermelha". 


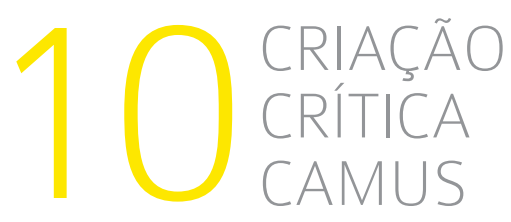

Em Camus, as imagens delineiam os dramas humanos, a atmosfera dos tempos, e como no caso da conferência A Crise do Homem permitem diagnosticar os sintomas das piores doenças contemporâneas:

Sim, existe uma Crise do Homem, já que a morte ou a tortura de um ser pode, em nosso mundo, ser examinada com um sentimento de indiferença ou de interesse cordial ou de experimentação, ou de simples passividade [...] visto que o extermínio de um ser pode ser visto de outra maneira que não a do horror e a do escândalo que deveria suscitar [...] é fácil demais acusar [...] somente Hitler e dizer que estando a besta morta o veneno desapareceu. Pois sabemos bem que o veneno não desapareceu, que nós o guardamos nos nossos próprios corações e isto se sente na maneira pela qual, as nações, os partidos e os indivíduos, ainda se olham com um resquício cólera. (CAmus, 2006, p. 739, tradução nossa)

É neste sentido que podemos compreender o teatro de Camus no contexto de seu engajamento ético, político e filosófico: diagnóstico e combate das raízes e dos frutos do totalitarismo e do fatalismo histórico, e mais particularmente, a peça Calígula, a partir da problemática do totalitarismo - da vontade de potência - e do niilismo filosófico contemporâneo.

A peça inicia-se com o retorno de um Imperador dilacerado pela experiência da saudade. Renascido dos elementos, maculado de barro e folhas, embebido de todos os sentidos da terra, é a dor provinda da morte de sua irmã e amante Drusilla que conduz o imperador Calígula a uma lúcida constatação sobre a condição demasiado humana: "Os homens morrem e eles não são felizes." (CAmus, 2006, p. 332, tradução nossa)

Desta evidência amarga trazida pela experiência pessoal da finitude, o imperador romano, homem-deus, deduz a lei cósmica da transitoriedade. Dilacerado pela dor da perda, Calígula procura um sentido para a transitoriedade da vida: sua obsessão pela lua encarna a busca por uma justificação, no limite, estética para um cosmo indiferente e destruidor, desproporcional à fragilidade humana:

[...] Eu sei também o que tu pensas. Quanta história por causa da morte duma mulher! Não, não é isso. Acredito recordar-me, é verdade, que há alguns dias a mulher que eu amava morreu. Mas, o que é o amor? Pouca coisa. Juro-te que esta morte não quer dizer nada, apenas significa uma verdade que torna necessária para mim a lua. (CAmus, 2006, p. 332, tradução nossa)

A descoberta da transitoriedade radical da vida é a lucidez clarividente de Calígula, e é esta verdade dilaceradora, reservada a poucos, que o imperador decide "democratizar", e impor ao seu povo. Poderoso, Calígula confere uma dimensão política, isto é colossal, à constatação da injusta ordem da morte ditada pelos deuses. Deus entre os deuses dos quais se considera rival, procurando exercer seu papel, ele apressa-se em pôr em curso uma vida que justifique a si mesma, amando-a dolorosamente como ela se dá, inscrita numa cosmologia da crueldade. Calígula, após a morte de sua amada, zelará - como um tirano vigilante - para que a ordem do cosmo se efetive, mimetizando sua cegueira, impulsionando o moto contínuo indiferente de um tempo (Aiôn $\left.{ }^{4}\right)$ que devora seus filhos:

\footnotetext{
${ }^{4}$ Nos referimos aqui especificamente ao emprego do termo por Heráclito: "Tempo (Aiôn) é criança brincando, jogando; de criança
} o reinado."(Fr.52)(HERÁCLITo, 1984, p. 84 ) 
[...]é porque tudo à minha volta é mentira, e eu, eu quero a verdade! E, justamente, tenho meios para obrigá-los a viver na verdade. Porque eu sei o que lhes falta [...] eles estão privados de conhecimento, porque lhes falta um professor que conheça aquilo que ensina. (CAmus, 2006, p. 332, tradução nossa)

Calígula apressa a ampulheta do tempo, gira a engrenagem da morte, demonstrando, pela vileza de suas ações em prol do Tesouro público ${ }^{5}$, pelo copioso recurso às punições e execuções de Estado, pelo menosprezo cotidiano à dignidade humana, a evidência cósmica da absurdidade e da injustiça que aprendeu com a desaparição de Drusilla: "Findaste por compreender que não é necessário ter feito algo para morrer." (CAmus, 2006, p. 346, tradução nossa) É a lógica de um cosmo indiferente em operação, convertida numa política de Estado assassina: "Decidi ser lógico e visto que tenho o poder, verão quanto alógica pode custar. Exterminarei os contraditores e as contradições. Se for necessário, começarei por ti". (CAmus, 2006, p. 336, tradução nossa ) A Cherea, Calígula exprime o raciocínio dos tiranos que desfrutam das prerrogativas de um cosmo que tudo absorve e absolve em sua magnitude impassível: "Este mundo é sem importância e quem o reconhece conquista sua liberdade [...] acabei de compreender a utilidade do poder [...] hoje, e pelo tempo que virá minha liberdade não tem mais fronteiras."(CAmus, 2006, p. 336-337, tradução nossa).

A metáfora do totalitarismo como uma peste, produzida pela convicção filosófica de que o homem não encontra fronteiras ou limites para sua liberdade ou para sua vontade de potência diante de um cosmo e de uma história indiferente, se cristaliza na rivalidade metódica de Calígula com a crueldade reservada aos deuses:

Farás fechar os celeiros públicos [...] digo que vai haver fome amanhã. Todo mundo conhece a fome, é uma peste. Amanhã, haverá peste. E pararei a peste quando me aprouver. [Explicando aos outros] É que, apesar de tudo, não tenho muitas maneiras de provar que sou livre. É-se sempre livre à custa de alguém... (CAmus, 2006, p. 359, tradução nossa)

Num mundo descrito com a clarividência dos olhos do físico de Éfeso, privado de ilusões, Calígula refundamenta a política, flutuante desde o crepúsculo dos ídolos - ela se alicerça doravante no esteio da crueldade natural do cosmo:

Para um homem que ama o poder, a rivalidade com os deuses tem algo de irritante. Suprimi isto. Provei a estes deuses ilusórios que, um homem, se tem vontade, pode exercer, sem aprendizagem, a ridícula profissão deles. (CAmus, 2006, p. 362, tradução nossa)

Os indícios estão dados, o Calígula de 1943 de Camus encarna a aurora de uma história considerada um "Novo Ídolo", pensamento e força de substituição às religiões conformadoras, que caducaram há tempos. Está na vontade de potência a "pedra de toque" da transladação "apolínea" da desgraça cósmica em virtude histórica, em condição do progresso humano, em método político. É a naturalização do crime que enaltece Calígula, fundamentando em razões filosóficas as práticas do poder sem medida: "É a clarividência.

5 "Se o Tesouro tem importância, então a vida humana não tem."(CAmus, 2006, p. 332) Inevitável ressaltar a triste atualidade do "contradiscurso" de Camus- tradição moraliste- sobretudo quando pensamos, por exemplo, na geopolítica internacional que hoje aniquila a cultura grega ou nas políticas públicas para a educação no Brasil. 


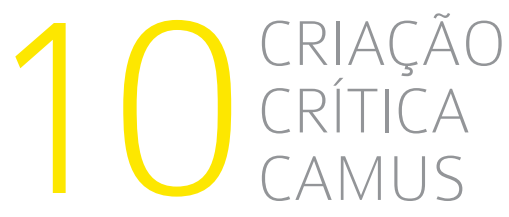

Eu simplesmente compreendi que não há senão uma maneira de se igualar aos deuses: é suficiente ser tão cruel quanto eles" (CAmus, 2006, p. 362, tradução nossa).

Vale reiterar: trata-se de uma refundamentação metafísica da política nos termos de uma cosmologia da crueldade que Camus cristaliza na figura de Calígula: como dirá Camus em O Homem Revoltado, "a filosofia pode servir para tudo, até mesmo para transformar assassinos em juízes” (CAmus, 1998, p. 13).

É neste sentido que é certo que Cherea seja o alter ego de Camus visto que, na versão de 1943, ele é interlocutor privilegiado do imperador e porta-voz do diagnóstico camusiano sobre a "doença" da vontade de potência:

Imperadores loucos, nós conhecemos. Mas este não é louco o bastante. E o que detesto nele, é que ele sabe o que quer [...] sem dúvida, não é a primeira vez que, entre nós, um homem dispõe de um poder sem limites, mas é a primeira vez que dele se serve sem limites, até negar o homem e o mundo. (CAmus, 2006, p. 342, tradução nossa)

Depois de seu diagnóstico clínico, a fala de Cherea desvela um engajamento inusitado aos olhos de um leitor desatento de Camus, a saber, o engajamento contra o nietzschianismo tornado niilismo pela política:

[Aos senadores] Partilharei [a vingança] com vocês. Mas compreendam que não é para tomar partido de suas pequenas humilhações. É para lutar contra uma grande ideia cuja vitória significaria o fim do mundo [...] ele transforma sua filosofia em cadáveres e, para nossa infelicidade, é uma filosofia sem objeções. (CAmus, 2006, p. 342-343, tradução nossa)

A prescrição de Cherea, sua metodologia para a deposição de Calígula fundamentada no próprio niilismo do imperador, nos remete ainda à metodologia que opera Camus em sua própria leitura de Nietzsche no artigo Niilismo e História, texto que integra O Homem Revoltado, no qual Camus investiga as consequências éticas e políticas últimas das premissas do filósofo da visão de Surlei: "É necessário empurrá-la em seu sentido, e esperar que esta lógica converta-se em demência" (CAmus, 2006, p. 343, tradução nossa).

Para Camus, portanto, a "grande ideia cuja vitória significaria o fim do mundo", a "filosofia que se transforma em cadáveres" é do ponto de vista de 1943, momento no qual uma reflexão sobre a vontade de potência alemã se impõe, o nietzschianismo " "politizado", herdeiro direto de uma atualização contemporânea da concepção heraclitiana do cosmo utilizado para uma legitimação da pura violência ou da potência e conquista sem limites. Calígula brada aos quatro ventos sua clarividência heraclitiana: "Eu sei que nada permanece! Oh, saber isto! Fomos apenas dois ou três na história que tivemos a verdadeira experiência disto, que pudemos atingir esta felicidade demente. (CAmus, 2006, p. 386, tradução nossa)

Ora, leia-se: Calígula, "ou o jogador", Nietzsche e Heráclito.

${ }^{6}$ Obviamente trata-se de um nietzschianismo de apropriação ideológica e banalizado pela política de seu tempo, possivelmente infiel aos propósitos íntimos do autor. Lembremos como Nietzsche se coloca contra os hábitos, os nacionalistas e os políticos alemães em Ecce Homo! Vale ressaltar, no entanto, que em O Homem Revoltado Camus conduzirá uma crítica bastante ampla aos desdobramentos éticos, políticos e históricos do pensamento de Nietzsche.

7 Caligula ou le joeur é o primeiro título concedido por Camus à peça segundo os Manuscritos dos Fundos Camus (version A).Notar ARNOLD, J-A. La poétique du Prémier Caligula,Camus lecteur de Nietzsche nos Cahiers Albert Camus 4. A passagem seguinte do Ecce Homo de Nietzsche da biblioteca de pessoal de Camus (edição de 1932), retém a atenção de James Arnold, ela se encontra "sublinhada, contrariamente ao hábito de Camus, à tinta, caprichosamente, com uma mão firme": "Não conheço outro modo de 
No cerne da experiência cósmico-existencial de Calígula está um fluido e radical cosmo que não se detém em seu jogo eternamente renovado de combate e de destruição, que se perpetua indiferentemente e à revelia de qualquer sentido ou justiça tributável humanamente. Calígula bem que poderia ter dito aos pés de Drusilla e antes de iniciar seus massacres: "Vejo o vir-a-ser" (NietZSCHE, 1992, p. 102).

A obsessão de Calígula pelo jogo, pelo divertissement no senso pascaliano, pela transgressão, pela recodificação fastidiosa dos valores, pela coisificação dos seres, pela atribuição arbitrária de deveres e de punições que tornam a singularidade humana ridícula e desprezível, em suma, pela eterna renovação do mundo através do movimento de destruição e criação, de vidas e de valores, advém desta assunção plena à concepção lúdica da existência, compreendida como império cego de um tempo-criança às voltas consigo mesmo: "Tempo (aiôn) é criança brincando, jogando; de criança o reinado" (HERÁcLIto, 1984, Fr.52, p.84).

$\mathrm{Na}$ ótica de Camus, as engrenagens do poder, munidas das premissas da inocência primordial, materializam historicamente as piores e mais nefastas consequências da descrição heraclitiana-nietzschiana de mundo, transformando a violência e a crueldade em um leitmotiv de toda uma época: "O combate é de todas as coisas pai, de todas rei, e uns revelou deuses, outros homens; de uns fez escravos, de outros livres" (HERÁClito, 1984,.Fr.53, p.84)

Calígula brande as palavras de ordem que fundamentam o cotidiano político de um cosmo cruel: "Quem ousaria me condenar neste mundo sem juiz..." (CAmus, 2006, p. 387, tradução nossa.).

Se a lição dos elementos nos ilustra uma desordem predadora como sendo a própria verdade e harmonia dissonante do cosmo, cuja lei e direito é um feroz combate pautado pela aniquilação, quem ousaria pautar uma política antinaturalista? "É preciso saber que o combate é o-que-é-com, e justiça (é) discórdia, e que todas (as coisas) vêm a ser segundo discórdia e necessidade" (Heráclito, 1984, Fr. 80, p.87).

Num universo no qual o crime é a própria lei, Calígula diz: "todas as coisas são equivalentes" (CAmus, 2006, p. 386, tradução nossa.). Se em Heráclito, "a rota para cima e para baixo é uma e a mesma", revela-se o projeto heraclitiano-nietzschiano do político conquistador contemporâneo matizado no Calígula de Camus: "Eu quero misturar o céu e o mar, confundir feiúra e beleza, fazer brotar o riso do sofrimento"8 (CAmus, 2006, p. 339, tradução nossa.).

lidar com grandes tarefas senão o jogo..." (Na versão brasileira, NiETZSCHE, F. Ecce Homo. p. 51.) Arnold subscreve: "É muito possível que este aspecto do jogo esteja em relação com o ato II do Calígula..."(Op.cit., p. 96) Outras frases em relação direta com o Calígula estão também grifadas, no volume do Crepúsculo dos ídolos utilizado por Camus e em seu volume de A Origem da Tragédia: "A afirmação da vida em seus aspectos mais estranhos e árduos; a vontade de vida...esta felicidade que traz ainda com ela a felicidade da nadificação[...]que a existência do mundo não pode se justificar senão como fenômeno estético[...]um deus puramente artista, absolutamente desprovido de escrúpulos e de moral, para quem a criação ou a destruição, o bem ou o mal são manifestações de seu capricho indiferente e de sua toda-potência; que se desembaraça, fabricando mundos, do tormento de sua plenitude..." (em Arnold, J-A. Camus leitor de Nietzsche. Em Cahiers Albert Camus 9, p. 96-98).

${ }^{8}$ Em Heráclito: "Direções do fogo: primeiro mar, e do mar metade terra, metade incandescência. Terra dilui-se em mar e se mede no mesmo logos, tal como era antes de se tornar terra."(Fr.31, p.82) "O deus e dia e noite, inverno verão, guerra paz, saciedade fome..."(Fr.67, p.85)“As (coisas) frias esquentam, quente esfria, úmido seca, seco umedece."(Fr.125,p.91). "O mel segundo Heráclito, é a um tempo amargo e doce, e o próprio mundo é um vaso de mistura que tem que ser continuamente agitado." (NiEZsCHE, 1992, p. 104) A ótica heraclitiana é retomada pelo Zaratustra de Nietzsche: "A dor é também um prazer, a maldição é também uma benção, a noite é também um sol; ide embora daqui, senão aprendereis: um sábio é também um louco.” (NIETZSCHE, 1995, p. 324). 
O desespero de Cesônia face ao projeto histórico-filosófico de Calígula, o do transfigurar a miséria em grandeza, quem sabe aluda à fúria de Aristóteles mencionada por Nietzsche contra a subversão heraclitiana: "Há o bom e o mau, o que é grande e o que é baixo, o justo e o injusto. Juro-te que isto não mudará!" (CAmus, 2006, p. 339, tradução nossa.).

Ora, para os que experimentaram os abismos da lucidez, como Calígula, Heráclito e Nietzsche, estas são certezas colapsadas pelas características cataclísmicas do universo. Como bem sabemos, a epistemologia heraclitiana-nietzschiana constitui irresistivelmente uma ética da indiferença moral: "Para o deus são belas todas as coisas e boas e justas, mas homens umas tomam (como)injustas, outras(como)justas" (Heráclito, 1984, Fr. 52).

Em A Filosofia da Época Trágica dos Gregos, Nietzsche louva este amoralismo inscrito no cosmo desvelado por Heráclito que transmuta "dor em prazer", naturalizando o eixo do combate pela sobrevivência como cerne da condição, a um só tempo, humana e cósmica: "Tudo ocorre conforme a esse conflito, e é exatamente este conflito que manifesta a eterna justiça"(NIETZSCHE, 1992, p. 104). Ele se detém na gênese desta imagem bélica do cosmo fornecida pelo físico de Éfeso:

Heráclito media o universo movido sem descanso, a"efetividade", com o olho do espectador afortunado, que vê inúmeros pares lutar em alegre torneio sob a tutela de rigorosos árbitros; não podia considerar os pares em luta e os juízes separados uns dos outros, os próprios juízes pareciam combater, os próprios combatentes pareciam julgar-se - sim, como no fundo só percebia a justiça uma, eternamente reinante, ele ousou proclamar: "o próprio conflito do múltiplo é a pura justiça." (Nietzsche, 1992, p. 105)

Nietzsche é um entusiasta desta "contemplação puramente estética do mundo" (NIETZSCHE, 1992, p. 108): "[Heráclito] ele ergueu a cortina desse espetáculo máximo." (NietZsCHE, 1992, p. 110).

O filósofo-músico admira a clarividência liberadora do mestre Heráclito no desvelamento deste cosmo indiferente e feroz que transfigura a guerra em dança:

É uma representação maravilhosa, haurida da mais pura fonte do helenismo, que considera o conflito como o império constante de uma justiça unitária, rigorosa, vinculada a leis eternas. Heráclito não tem nenhuma razão para ter que demonstrar como Leibniz que este mundo é o melhor de todos; bastava-Ihe que ele fosse o belo, o inocente jogo do Aiôn. (NieTZSCHE, 1992, p. 104105)

Nietzsche exclama a partir de Heráclito: "Quem pedirá ainda de tal filosofia uma ética?"(NIETZSCHE, 1992, p. 108) Calígula os acompanha: "Quem ousará me condenar neste mundo sem juiz?" (CAMus, 2006, p.387, tradução nossa.).

Da concepção de cosmo heraclitiano, Nietzsche deduz até suas últimas consequências éticas e filosóficas, e observa que as ideias seu mestre exigem o estabelecimento de um prisma artístico-aristocrático para serem compreendidas:

9 '“Tudo tem, em todo tempo, o oposto em si', com tanta insolência que Aristóteles o acusa de crime supremo diante do tribunal da razão, de ter pecado contra o princípio de não contradição"(Nietzsche, 1992, p. 103). 
Há culpa, injustiça, contradição, dor neste mundo?Sim, exclama Heráclito, mas somente para o homem limitado, que vê em separado e não em conjunto, não para o deus constitutivo; para este, todo conflitante conflui em harmonia, invisível, decerto, ao olho humano habitual, mas inteligível àquele que, como Heráclito, é semelhante ao deus contemplativo. Diante de seu olhar de fogo, não resta nenhuma gota de injustiça no mundo esvaído em torno dele; e mesmo aquele espanto cardeal - Como pode o fogo assumir formas tão impuras?- é superado por ele com uma comparação sublime. Um vir-a-ser e perecer, um construir destruir, sem nenhum discernimento moral, eternamente na mesma inocência, têm, neste mundo, somente o jogo do artista e da criança. E assim como joga a criança e o artista, joga o fogo eternamente vivo, constrói e destrói em inocência - e esse jogo o Aiôn joga consigo mesmo. (NIETZSCHE, 1992, p.107)

Calígula, o jogador, encarna a dimensão política, histórica, do usufruto pleno destas prerrogativas de inocência "libertícidas" extraídas deste segredo "prometeico", para poucos, apenas insinuado por Heráclito: "Este mundo não tem importância e quem o sabe, conquista sua liberdade [...] minha liberdade não tem mais fronteiras" (CAmus, 2006, pp.326-7, tradução nossa.).

Nietzsche assume em diversos momentos de sua obra, tal como Heráclito reivindica violentamente, esta dimensão aristocrática para sua filosofia, segundo ele, inacessível ao "homem limitado" e reservada "somente ao homem estético", único capaz de "intuir o mundo"(NiETZSCHE, 1992, p.107): "Pois cães ladram contra os que eles não conhecem" (HERÁclito, 1984, Fr.97, p.88)."Pois cadáveres, mais do que estercos, são para se jogar fora" (Heráclito, 1984, Fr. 96, p.88). "O asno prefere a palha ao ouro"(NietzsChe, 1992, p.107, p.89): "Porcos em lama se comprazem, mais do que em água limpa”(Heráclito, 1984, Fr. 13,p.80).

Quem sabe respirar o ar dos meus escritos sabe que é um ar das alturas, um ar forte. É preciso ser feito para ele, se não há o perigo de se resfriar. O gelo está próximo, a solidão é monstruosa - mas quão tranquilas banham-se as coisas na luz! Com que liberdade se respira! (NieTZsCHE, 1993, p.18)

"Más testemunhas para os homens são olhos e ouvidos, se almas bárbaras eles tem" (HERÁcLito, 1984, Fr. 102). Esta dimensão aristocrática do saber é requerida para a compreensão adequada da condição humana inscrita no cosmo indiferente heraclitiano-nietzschiano:"Sombrio, melancólico, lacrimoso, escuro, atrabiliário, pessimista e, de modo geral, odioso, só acham de Heráclito aqueles que não têm motivo para ficar satisfeitos com sua descrição natural do homem" (NietZsChe, 1992, pp.108-9).

Calígula, aliás, como Zaratustra, está para além do aristocrata -"conquistei a divina clarividência do solitário"10 (CAmus, 2006, p. 329, tradução nossa.). O imperador, assim como o real Heráclito, encontra-se, obviamente, para além de bem e mal: "Tais homens vivem em seu próprio sistema solar"(NiETZsCHE, 1992, p. 110). Calígula, em seu universo "artístico", de deus constitutivo e contemplativo, cercada pelos jogos, pela música, pela poesia, pelo teatro vivo, em seu obsessivo desvelo pela destruição e pelo crime, encontra-se absolutamente à vontade e integrado em sua arte de viver. Imperador e artista dionisíaco, Calígula, em sua "concepção estética básica do jogo do mundo" (NietZSCHE, 1992, p. 109) está além das fronteiras morais e seus excessos são constitutivos de sua arte de amar a vida: "Não é o ânimo criminoso, mas o impulso lúdico

${ }^{10}$ Lembremos que até aos "homens superiores", Zaratustra abandona no desfecho de seu percurso: "Pois bem! Ainda dormem, esses homens superiores, quando eu já estou acordado: não são esses os companheiros próprios para mim!”(Nietzsche, 1995, p. 326) 
que sempre desperta o novo, que chama à vida outros mundos. Às vezes, a criança atira fora o seu brinquedo: mas logo recomeça, em humor inocente." (NIETZSCHE, 1992, p. 107)

Se Calígula aniquila, pouco a pouco, a todos, arrasando um a um, em cena, em banhos de sangue, cada um dos coadjuvantes de seu espetáculo, desfilando na cidade suas alegorias da crueldade - "É um jogo, não o tomeis tão pateticamente e, antes de tudo, não o tomeis moralmente"(NIETZSCHE, 1992, p. 108)- isto é apenas a sua dança. Ele é o "homem estético"(NietZSCHE, 1992, p. 107) de Nietzsche legitimando sua moral aristocrática de artista-tirano através de uma filosofia prática do combate e da transitoriedade. Aprendamos com o músico,

assim intui o mundo somente o homem estético que aprendeu com o artista e com o nascimento da obra de arte como o conflito da pluralidade pode trazer consigo lei e direito, como o artista fica em contemplação e em ação na obra de arte, como necessidade e jogo, conflito e harmonia tem de emparelhar-se para gerar a obra de arte.(NIETZSCHE, 1992, p. 107-108)

Calígula diz, conferindo "calor e rosto" à concepção lúdica e estética da existência de Nietzsche:

O erro de todos estes homens é de não crer o bastante no teatro. Sem isto, eles saberiam que é permitido a todo homem representar [jouer] tragédias celestes e tornar-se deus. É suficiente endurecer o coração. (CAmus, 2006, p. 363, tradução nossa.)

Ator, ele mimetiza a crueldade e a indiferença do cosmo até a completa desfiguração humana: "Não se compreende o destino, e é por isso que me fiz destino. Tomei o rosto animalesco e incompreensível dos deuses" (CAmus, 2006, p. 363, tradução nossa).

A alusão à máscara dionisíaca do Zaratustra-Nietzsche do autor que finaliza sua autobiografia filosófica, Ecce Homo, explicando - "Por que sou um destino"- não é uma mera coincidência. Nas palavras de Raymond Gay-Crosier (1967), Calígula é o ermitão de Silvaplana transferido para uma ambientação romana, na qual ele tem, por uma vez somente, a chance de realizar suas ideias, e jogar seu jogo cruel até o fim. Diante de universo tão cruel - e com professores tão argutos - não é à toa, portanto, que o vigilante obreiro do caos, Calígula, assuma obstinadamente a reivindicação do "impossível"11 da "lua"12, que justificaria seu ímpeto insaciável de existir esteticamente na beleza e na plenitude - "Eu ainda não esgotei tudo aquilo que me faz viver. É por isso que quero a lua" (CAmus, 2006, p. 365, tradução nossa).

Como diz Zaratustra -"Acaso a lua não nos embriaga?" (NIETZSCHE, 1995, p. 321).a lua é o símbolo supremo desta busca pela transfiguração trágica da dor em prazer -espécie de hóstia ou de Santo Graal - procurada seja pelo ébrio dionisíaco, seja pelo tirano-artista.

Zaratustra e Calígula procuram, embora de modos diferenciados, redenção e justificação cósmica na lua, isto é, na estética, na beleza, na arte - no movimento bramânico de criação e destruição. Trata-se de um movimento de "eternização" no instante, pela efetivação e contemplação do vir-a-ser:

\footnotetext{
11 "Este mundo, tal como é, não é suportável. Eu, então preciso da lua ou da felicidade, ou da imortalidade, de qualquer coisa que seja demente talvez, mas que não seja desse mundo"(CAmus, 2006, p. 331, tradução nossa.)."Somos dois ou três na história a ter feito verdadeiramente a experiência disto, e a atingir esta felicidade demente" (CAmus, 2006, p. 386, tradução nossa.).

12 "A morte não é nada, te juro: ela é apenas o sinal de uma verdade que torna a lua necessária". (Camus,2006, p. 332, tradução nossa.).
} 
Todo o prazer quer eternidade para as coisas. Ó homens superiores, por vós almeja o prazer, o indomável, bem-aventurado - almeja pelo vosso sofrimento, ó criaturas malogradas! Por coisas malogradas, almeja o eterno prazer... Aprendeste agora o meu canto? Adivinhaste o que ele quer? Cantai para mim, agora, homens superiores, a minha cantiga de roda![...] Profundo é o mundo! E mais profundo do que pensa o dia. Profundo é o seu sofrimento - E o prazer - mais profundo que a ansiedade. A dor diz: "Passa, momento!" mas quer todo o prazer eternidade. Quer profunda, profunda eternidade. (NIETZSCHE, 1995, p. 321)

Vivo, mato, exerço o poder delirante do destruidor, ao pé do qual o do criador parece uma macaquice. É isso ser feliz. É isso a felicidade, essa insuportável libertação, esse desprezo universal, o sangue, o ódio em meu redor, esse isolamento sem par do homem que põe toda a sua vida diante de si, a alegria desmedida do assassino impune, essa lógica implacável que rebenta as vidas humanas, que te destrói Cesônia, para perfazer, enfim, a solidão eterna que desejo. (CAmus, 2006, p. 387, tradução nossa.)

Calígula desempenhará o solitário papel de protagonista do tempo (Aiôn) até o desfecho lógico de seu jogo, com a lucidez de um teórico refinado das artes do combate, mas, sobretudo, com a embriaguez de um esteta e de um contemplador convicto. Guiado pelo sopro de sua própria concepção lúdica da vida, com indiferença, ele se presta a protagonizar o papel de presa na armadilha que o conluio do tempo, por ele semeado, Ihe arquiteta. Seu exercício, por três anos, de uma rigorosa política fundamentada no mimetismo da crueldade cósmica, revela, afinal, um subliminar projeto suicida.

Na cena final da versão de 1943 do Calígula de Camus coabitam, afinal, desenlace trágico e engajamento filosófico na medida em que o golpe "em pleno rosto" (CAmus, 2006, p. 388) de Cherea em Calígula encarna a recusa de uma "filosofia que se transforma em cadáveres" (CAmus, 2006, p. 343, tradução nossa) e o compromisso intelectual de "lutar contra uma grande ideia cuja vitória significaria o fim do mundo" (CAmus, 2006, p. 342, tradução nossa).

O sentido engajado da peça, orientado num horizonte que problematiza a questão da responsabilidade intelectual, é evidenciado no diagnóstico de Cherea sobre o jogo poético-existencial de Calígula: "É preciso, pois, compreender, que isto trata do poder assassino da poesia" (CAmus, 2006, p. 349, tradução nossa).

Sem dúvida, para Camus, Calígula não é somente uma refutação da vontade de potência nietzschiana, é preciso vê-lo como um processo inclemente contra o totalitarismo. O verídico é tão claro quanto simples: o pensamento conquistador é culpado sob qualquer aspecto. (GAY-Crosier, 1967, p. 114)

A dimensão ética antinietzschiana que o autor lhe infunde em meio à luta viva contra o totalitarismo da Segunda Grande Guerra, provoca, num indício importante do liame entre engajamento literário e engajamento filosófico em Camus, até mesmo a incorporação, na versão de 1943, de um mea culpa de Calígula que fere a extrema coerência deste "herói" trágico, bem preservada na versão de 1941. Como comenta James Arnold: "Esta abjuração de si impõe ao protagonista e a seu destino trágico o reconhecimento de uma falta moral que vai de encontro às intenções originais do autor" (ARNOLD, 1984, p. 172). 
Um Calígula demasiado shakespeariano, demasiado visceral ${ }^{13}$, some da versão madura: "Se eu tivesse tido a lua, ou Drusilla, ou o mundo, ou a felicidade, tudo teria mudado!" (CAmus, 1984, p. 118, tradução nossa.) E, sobretudo, uma tomada de consciência contemporânea é incorporada à trama eticamente engajada do autor que concebia ao mesmo tempo, debatendo o niilismo contemporâneo alemão, as "Lettres à un ami allemand"14.

[Calígula estende as mãos para o espelho] "Procurei o impossível nos limites do mundo, nos confins de mim mesmo ${ }^{15}$.Estendi as minhas mãos[gritando],estendo as minhas mãos e é a ti que encontro, sempre a ti diante de mim, e eis-me cheio de ódio diante de ti. Não escolhi o caminho que era preciso, não cheguei à nada. Não é certa a minha liberdade! ${ }^{16}$ (CAmus, 2006, p. 342, tradução nossa)

É importante assinalar, no entanto, que em ambas as versões do Calígula de Camus se pode observar o mesmo presságio lúcido, o de uma terrível história em elaboração, prenunciado pelas derradeiras palavras do imperador antes de sucumbir à lógica predadora da qual se fez pedagogo:

À história, Calígula, à história. [O espelho quebra-se e, nesse instante, entram por todas as portas os conjurados, as armas. Calígula faz-lhes frente, com um riso de louco. O Velho Patrício fere-o pelas costas, e Cherea em pleno rosto ${ }^{17}$. O riso de Calígula se transforma em soluços. Todos os ferem. Num último soluço, Calígula, rindo e estrebuchando, grita]: Ainda estou vivo! (CAmus, 2006, p. 388, tradução nossa)

Trata-se da evidenciação do intertexto político e histórico desta obra de teatro seguramente engajada no desmascaramento das imposturas políticas e filosóficas, e assim, dialogicamente, comprometida com a construção de uma "ética da solidariedade nascida da experiência da Europa esmagada pela tirania" (ARNOLD, 1984, p. 175).

Contudo, seria temerário sublinhar tão somente os aspectos tirânicos do Calígula de Camus sem aludir à sua inquietante simpatia em cena. Por exemplo, qualquer espectador da encenação de Charles Berling em 2005 em Paris, no Théâtre de l'Atelier - montagem que conservando fidelidade absoluta ao texto camusiano, encarna sua mensagem sobre o poder num cenário atual, o dos elegantes políticos engravatados em seus reservados "palácios" e arranha-céus, nos quais se decide da vida e da morte, para além de bem e mal - defronta-se, de chofre, com a ambiguidade da figura de Calígula.

Além de um apaixonado, de um lírico dotado de um coração de poeta, o tirano de Camus é - inicialmente um portador da justa revolta contra a ordem da finitude: "de que me serve poder tão admirável se não posso mudar a ordem das coisas, se não posso fazer que o sol ponha-se no leste, que o sofrimento decresça e que os

13 "Sou para ti cheio de ódio - e tu és para mim como uma ferida que eu gostaria de dilacerar com minhas unhas para que o sangue e o pus misturados à minha vida saiam em gordas borbulhas."(CAmus, 1984, p. 118, tradução nossa.)

${ }^{14}$ O vocabulário de Cesônia desvela que nos encontramos no mesmo registro, histórico e ético, das "Lettres à un ami allemand": "[...] se o mal está sobre a terra, porque querer a ele acrescentar[pourquoi vouloir y ajouter]?" (CAmus, 2006, p. 338) "É que admites o bastante a injustiça de nossa condição para resolver a ela acrescentar [ajouter], enquanto me parece que o homem deveria afirmar a justiça para lutar contra a injustiça eterna."(CAmUs, 1965, p. 240)

15 "Procurei-me a mim mesmo." (Heráclito, 1984, Fg.101 p.88).

${ }^{16}$ Perceber que Maria diz a Jan em O Equívoco (I, 4): "seu método não é o certo[ta méthode n'est pas la bonne]" (CAMus, 2006, p. 464, tradução nossa).

17 "Cherea está sobre ele e o fere com seu punhal, três vezes no rosto..." Única diferenciação em relação à cenografia do desfecho da versão de 1941. (CAmus, 2006, p. 388 e CAmus, 1984, p. 119, tradução nossa.) 
homens não morram mais?" (CAmus, 2006, p. 338, tradução nossa). Sua reação ao destino humano absurdo oscila entre a rivalidade e o mimetismo apaixonado da crueldade cósmica, procedimento que se cristaliza num populismo sanguinário:

Minha vontade é de mudar. Eu darei a este século o presente da igualdade. E quando tudo estiver aplainado, o impossível enfim sobre a terra, a lua em minhas mãos, então, talvez, eu mesmo estarei transformado e o mundo comigo; então, enfim, os homens não morrerão e eles serão felizes. (CAmus, 2006, p. 339, tradução nossa)

É este projeto de eternidade - cujo fim é de um populismo exacerbado como atesta a frase acima - que legitima Calígula no exercício de sua metodologia do saque e do crime generalizados. Tudo é permitido em prol do Tesouro público que sintetiza sua metodologia conquistadora: "O amor, Cesônia! [Ele a toma nos braços e a sacode] Aprendi que isto não é nada! É outro que tem razão: o Tesouro público. Compreendeste, não é? Tudo começa com isso..." (CAmus, 2006, p. 339, tradução nossa).

O Calígula de paletó de Camus-Berling exprime a realpolitik, o intercâmbio entre seres, valores e produtos, nesta indistinção amoral característica do universo contemporâneo mercantilizado ao limiar do absurdo em todas as suas dimensões, incapaz de distinguir entre as esferas, pública e privada, obcecada pela ideia do acúmulo e pela "ética da quantidade":

O Tesouro é de um interesse potente. Tudo é importante: as finanças, a moralidade pública, a política exterior, o aprovisionamento do exército e as leis agrárias! Tudo é capital. Tudo está no mesmo pé: a grandeza de Roma e as crises de artrite. Tratarei de tudo isto! (CAmus, 2006, p. 334, tradução nossa.)

Há algo de tragicômico nesta encarnação da metodologia e dos pressupostos do poder político-econômico, ancorado na lógica da indistinção e da prepotência, conduzidos ao paroxismo - ao deboche; Calígula guia a plateia em direção a um riso desconfortável:

Escute bem, imbecil. Se o Tesouro tem importância, então a vida humana não tem. Isto é claro. Todos aqueles que pensam como tu devem admitir este raciocínio e ter sua vida por nada visto que pensam que o dinheiro é tudo. Enquanto isto, eu decidi ser lógico e já que tenho o poder, verás quanto esta lógica irá vos custar. Eu exterminarei os contraditores e as contradições. Se for preciso, começarei por ti. (CAmus, 2006, p. 335-336, tradução nossa)

Esta simpatia mórbida de Calígula entra em cena principalmente porque o espectador é conduzido a partilhar com o "herói" o desprezo pela ambientação cortesã, palaciana, corrompida e viciada - isto é, política (no senso brasileiro do termo) - que o cerca. Assim, como não compactuar - ainda que pelo riso - com a lógica da voracidade, quando ela é, pela primeira vez, aplicada à risca aos seus mais proeminentes mentores, tantas vezes triunfantes em sua impunidade?

Vamos, seção três, parágrafo primeiro. [Helicon, se levanta e recita mecanicamente] "A execução conforta e liberta. Ela é universal, fortificante e justa em suas aplicações assim como em suas intenções. 
Morre-se porque se é culpado. Se é culpado porque se é sujeito a Calígula. Ora, todo mundo é sujeito a Calígula. Logo, todo mundo é culpado. Donde se conclui que todo mundo morre. É uma questão de tempo e de paciência." (CAmus, 2006, p. 359, tradução nossa.)

Enigma da "cordialidade", assim como aniquila facilmente, o Calígula de Camus ama e é amado facilmente: "Sou puro no bem, como sou puro no mal" (Camus, 2006, p. 359, tradução nossa.)

Além desta franja lírica da revolta de Calígula contra a finitude, outro aspecto caro às preocupações de Camus ajuda a delinear os traços ambíguos que compõem o retrato do artista e tirano: na pele de Calígula vemos o horizonte trágico de uma política que, apesar de virtualmente nobre, está fadada ao fracasso pelo desprezo dos métodos pelos quais se efetiva. Trata-se do messianismo historicista, que, segundo Camus, confunde as dimensões histórica e metafísica da condição humana numa política pautada em função da construção da eternidade e não do presente. Camus afirma em O Mito de Sísifo, "uma revolução é sempre contra os deuses [...].Trata-se de uma reivindicação humana contra o seu destino" (CAmus, 2004, p. 102). Ora, a voracidade de Calígula, que deseja o "impossível enfim sobre a terra", "a lua nas mãos", encarna o potencial transgressor e destruidor da justa reivindicação humana contra o absurdo da condição humana, quando esta desconhece a noção de limite. Há, afinal, muitos traços de interrogações evidentemente camusianas complementares ao perfil nietzschiano deste "Zaratustra político", esteja ele de toga ou de paletó.

É neste sentido que James Arnold e Raymond Gay-Crosier confluem em apontar que as transformações atestadas entre o primeiro e o Calígula maduro sinalizam para a evolução da própria interpretação camusiana de Nietzsche à luz da experiência da Segunda Grande Guerra:

A reescritura de Calígula em 1943 é feita em função de uma mudança estratégica em seu pensamento. A utilização racista que os nazistas haviam feito de Nietzsche - restando os escritos de Alfred Rosenberg sem dúvida o exemplo mais lúgubre - estimulou uma viva reação em Camus. Não teria servido nada insistir, em 1943, para lembrar que Nietzsche havia divisado seu Super-homem como um criador de valores superiores, e mesmo a repugnância que o nacional socialismo alemão nele tinha inspirado pesaram pouco na balança, em face da conduta bárbara dos SS e de outros super-homens do momento. É certamente em nome da resistência intelectual e artística contra uma vontade de potência global, que Camus pôde operar, publicamente, esta transmutação de seus próprios valores. (ARNOLD, 1984, p. 169-175)

Um fragmento dos Cadernos de fevereiro de 1943 demonstra que Camus opera a partir de um raciocínio pascaliano - trata-se da metodologia do renversementcontinueldupouraucountre- uma escolha refletida em favor de um engajamento contra ou, pelo menos, para além de Nietzsche:

Um espírito um pouco experimentado à ginástica da inteligência sabe, como Pascal, que todo erro vem de uma exclusão. Mas, a ocasião força a escolha. Foi assim que pareceu necessário a Nietzsche atacar com argumentos de força Sócrates e o cristianismo. Mas é assim ao contrário que é necessário que nós defendamos hoje Sócrates, ou ao menos o que ele representa, visto que a época ameaça substituí-lo por valores que são a negação de toda a cultura e que Nietzsche arrisca obter aqui uma vitória a qual ele não desejaria. (CAmus, 2006, p. 984, tradução nossa). 
James Arnold resume a escolha filosófica de Camus que, como veremos oportunamente, se prolongará com a crítica de Nietzsche elaborada em O Homem Revoltado: "Doravante, e até o fim da guerra, Camus irá queimar o que havia adorado. Ele escreverá sobre Nietzsche comentários que não se compreendem senão num contexto de luta contra o totalitarismo." (ARNOLD, 1984, p. 169)

Segundo Arnold, que manifesta um comentário arriscado e bastante difícil de ser fundamentado, diante das transformações submetidas ao substrato ético da versão de 1943, diante do imperativo "de liquidar as ocorrências do nietzschianismo em sua própria obra", começando por Calígula, "estamos em presença de um fenômeno bastante raro: um escritor que empreende pensar e escrever contra si mesmo porque entrevê e teme a perversão provável de uma verdade da qual ele ainda se encontra tributário"(ARNOLD, 1984, p. 173).

Neste ponto determinado, Gay-Crosier e Weyembergh nos parecem ainda mais lúcidos ao preferirem notar de maneira menos audaz um simples amadurecimento da leitura camusiana de Nietzsche e de Heráclito reinterpretados diante das solicitações de seu tempo.

Weyembergh ressalta, aliás, a pertinência ética e filosófica da leitura camusiana de Nietzsche durante a Segunda Guerra, aproximando-a da interpretação de Lukàcs para quem as "qualidades de Nietzsche o fazem bem mais perigoso do que o nacional-socialismo":

Se Nietzsche é, por suas qualidades, incomparavelmente superior às ideologias nazistas, não é menos verdade que sua doutrina de adesão ao mundo e o eterno retorno fecham o universo sobre ele mesmo, eternizam e transfiguram os conflitos e a violência que aí reinam. A ausência de transcendência, vertical ou horizontal que daí resulta aproxima incontestavelmente Nietzsche da concepção nacional-socialista de um universo livrado sem fim à luta das espécies e das raças. (WEYEMBERGH, 1980, p. 229)

Camus, afinal, parece amadurecer, "sob a pressão da história" (CAMus, 1965, p. 1705) sua interpretação do pensamento do herdeiro de Heráclito. Se a constatação do absurdo presente em O Mito de Sísifo é válida na maturidade filosófica do autor, permanecendo tributária de uma epistemologia heraclitiana-nietzschiana do cosmo, eticamente, entretanto, Camus almeja ultrapassar tanto a descrição do físico de Éfeso, quanto do contemplador esteta de Surlei: o autor argelino reivindica o prisma do filósofo socrático, ou do homem de virtù, em luta contra um infortunado destino humano comum. Mero resistente, estrangeiro, insurgente contra o conluio da Fortuna e da violenta indiferença universal.

Duas pedras, duas visões de mundo.

Enquanto Nietzsche com a visão da pedra de Surlei contempla o eterno retorno do processo bramânico de criação e destruição - "o mundo absurdo não recebe senão uma justificação estética" (CAmus, 2006, p. 974, tradução nossa) - o Sísifo de Camus envergado, mas altivo sob o peso da pedra do destino que enfrenta de sol a sol, vivencia, lucidamente, o drama da condição cósmica absurda: "sua rocha é a sua morada" (CAmus, 2004, p. 140).

Duas concepções filosóficas que afinal se entrechocam, pois para Camus não há "pedra filosofal" capaz de transformar a dor em prazer, a injustiça em justiça, o assassinato em lei, a contingência radical e feroz em um cultivado eterno retorno. Embora "seja necessário imaginar Sísifo feliz" (CAmus, 2004, p. 141), "é necessário", por outro lado, "ser um louco ou um covarde para consentir na peste, e, em face dela, a única palavra de ordem de um homem é a revolta” (CAmus, 2006, p. 978, tradução nossa). 


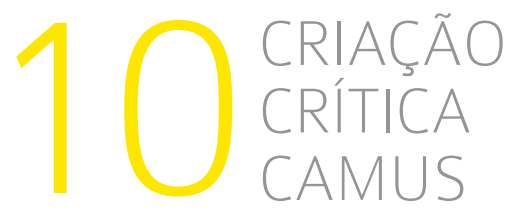

De todo modo, o veredicto de Camus sobre Nietzsche em 1943 é contundente e se materializa com força no Calígula que encarna as consequências lógicas últimas da naturalização do crime por intermédio de uma concepção puramente estética ou lúdica da existência e do cosmo.

Camus assinala a consequência lógica, histórica e política da assunção ao vale-tudo da inocência cósmica: a legitimação do assassinato em massa pela espiral da indiferença, num universo político prenhe de nostalgia do absoluto e livrado às lutas abissais das espécies em franco combate pela crua preponderância.

É neste sentido que a leitura camusiana de Nietzsche nos parece, hoje, novamente, em meio à efetivação definitiva de uma geopolítica internacional ditada pelas potências das paixões, pela conquista e pela indiferença, e de uma política interna governada pela violência reiterada e o cinismo impassível, perfeitamente compreensível. Ora, no entanto, vale relembrar, Camus "escreverá sobre Nietzsche comentários que não se compreendem senão num contexto de luta contra o totalitarismo". (ARNOLD, 1984, p.169).

\section{REFERÊNCIAS BIBLIOGRÁFICAS}

Camus, A. O Mito de Sísifo. Rio de Janeiro: Record, 2004.

Camus, A. O Homem Revoltado. Rio de Janeiro: Record, 1998.

Camus, A. Oeuvres Complètes. Paris : Gallimard, 2006.

Camus, A. Essais.Paris : Gallimard, 1965.

Camus, A. Thêatre, Récits, Nouvelles. Paris : Gallimard,1964.

Camus, A. Caligula version de 1941. Cahiers Albert Camus 4.Paris : Gallimard, 1984.

Camus, A. Combat Clandestin. Cahier Albert Camus 8. Paris : Gallimard, 1993.

Gay-Crosier, R. Les envers d'un échec. Étude sur le théâtre d'Albert Camus.Paris : Minard,1967.

Heráclito. "Fragmentos". In:Pré-Socráticos. Trad. José Cavalcante de Souza. São Paulo: Abril, Col.Os Pensadores, 1984.

ARNoLD, J. La poétique du premier Caligula.Camus lecteur de Nietzsche.Cahier Albert Camus 4.Paris : Gallimard, 1984.

Nietzsche, F. A Filosofia na Época Trágica Grega.São Paulo: Cia das Letras, 1992.

Nietzsche, F. Zaratustra. São Paulo: Círculo do Livro, 1995.

Nietzsche, F. Ecce Homo.São Paulo: Cia das Letras, 1993.

SARTRE, J-P. Situations IV. Paris : Gallimard, 1963.

Weyembergh, M. "Camus et Nietzsche: évolution d'une affinité". In: Albert Camus 1980.University of Florida Book. State of Florida, 1980.

REFERÊNCIA ELETRÔNICA: GERMAno, Emanuel R. Combate ao niilismo e ao totalitarismo em Camus: um contraponto teatral e filosófico às concepções lúdicas e estéticas da existência. Revista Criação \& Crítica, n. 10, p. 23-37, maio 2013. Disponível em: <http://www.revistas.usp.br/criacaoecritica〉. Acesso em dd mmm aaaa. 